\title{
Polyarthritis due to systemic lupus erythematosus in a dog
}

[Poliartrite por lúpus eritematoso sistêmico em um cão]

\author{
R.M. Krüger ${ }^{1}$, R.T. França1, A.S. Amaral ${ }^{2}$, J.E.W. Schossler ${ }^{2}$ \\ ${ }^{1}$ Aluno de pós-graduação - Universidade Federal de Santa Maria - Santa Maria, RS \\ ${ }^{2}$ Universidade Federal de Santa Maria - Santa Maria, RS
}

\begin{abstract}
A five year old male mongrel dog was presented for medical consultation with a history of arthralgia. Complete blood count revealed linfopenia and neutropenia, antinuclear antibody was positive at 1:1,256, and synovial fluid analysis showed inflammatory arthritis with lupus erythematosus cells. No significant proteinuria was detected on urinalysis, and microalbuminuria measurement was performed to determine glomerulonephritis in early stage. Based on clinical signs, synovial fluid analysis, antinuclear antibody test and complete blood count, the diagnosis was systemic lupus erythematosus. The measurement of microalbuminuria was useful to demonstrate the absence of glomerulonephritis, and the performance of complementary tests proved to be indispensable for diagnosis and prognosis. Glucocorticoid treatment led to complete remission.
\end{abstract}

Keywords: dog, lupus erythematosus cells, microalbuminuria, rheumatology

\section{RESUMO}

Foi atendido um cão com cinco anos de idade sem raça definida, macho, por apresentar artralgia. $O$ hemograma revelou linfopenia e neutropenia, o anticorpo antinuclear foi positivo em 1:1.256 e a análise de líquido sinovial demostrou artropatia inflamatória com células de lúpus eritematoso. Não foi detectada proteinúria significativa na urinálise, e exame de detecção de microalbuminúria foi realizada para determinar glomerulonefrite em fase inicial. Baseado em sinais clínicos, análise do líquido sinovial, teste de anticorpos antinucleares e hemograma, o diagnóstico foi lúpus eritematoso sistêmico. A mensuração da microalbuminúria mostrou-se útil para demonstrar ausência de glomerulonefrite, e a realização de exames complementares mostrou-se indispensável para o diagnóstico e o prognóstico. $O$ tratamento com glicocorticoides levou à remissão completa dos sinais clínicos.

Palavras-chave: cão, células lúpus eritematoso, microalbuminúria, reumatologia

\section{INTRODUCTION}

Systemic lupus erythematosus (SLE) is a multisystem chronic auto-immune disease, in which the immunity is directed against a variety of tissues or tissue components (Bennett, 1987). Lupus seems to result from loss control of B cells, leading to polyclonal gammopathy and subsequent production of multiple autoantibodies, starting a broad spectrum clinical manifestations and pathological lesions (Tizard, 2004). It is described in humans and other primates such as mice, horses, cats and dogs, whose incidence is higher in pure-bred,

Recebido em 1 de dezembro de 2011

Aceito em 4 de dezembro de 2012

E-mail: renankruger@yahoo.com.br mostly German shepherds, collies and Shetland sheepdogs (Monier et al., 1988; Fournel et al., 1992; Tizard, 2004).

The most common clinical signs include lameness by polyarthritis, skin lesions, petechiae, or bruising caused by vasculitis or thrombocytopenia, icteric mucous membranes resulting from immune-mediated hemolysis, and edema or ascites due to hypoalbuminemia secondary to glomerulonephritis (Bennett, 1987; Fournel et al., 1992). Complete blood count (CBC) may reveal hemolytic anemia, thrombocytopenia, neutropenia, and hyperproteinemia, except when renal loss of albumin is present (Jones, 1993). 
A typical feature of SLE is the development of autoantibodies against antigens in cell nucleus, the antinuclear antibodies (ANA), also called antinuclear factor (Tizard, 2004). A reactive ANA test of 1:256 or above is found in most dogs with SLE, and disease severity correlated positively with upward titration reagent (Fournel et al., 1992). Dogs seem to develop antinuclear antibodies against certain proteins and for histones $\mathrm{H} 1, \mathrm{H} 2 \mathrm{~A}, \mathrm{H} 3$ and $\mathrm{H} 4$, but do not develop against native double-stranded DNA (anti-ds) as occurs in humans, and the antihistone test should be performed when ANA is inconclusive (Costa et al., 1984; Fournel et al., 1992; Monestier et al., 1995).

The diagnosis of SLE is established after careful evaluation of clinical, haematological and serum biochemical analysis, as well as results of immunological tests (Jones, 1993). In humans, four of 11 criteria must be observed to confirm the diagnosis of SLE: malar rash, discoid rash, photosensitivity, oral ulcers, nonerosive arthritis, pleuritis or pericarditis, renal disease, neurological disorders, hematological disorders (cytopenias), positive ANA, or positive results for anti-DNA, anti-Sm or antiphospholipid antibodies (Hochberg, 1997). Although the human classification is used for the diagnosis of lupus in dogs, if these criteria are admitted strictly, many dogs with SLE do not correspond to reality (Jones, 1993; Day, 2008). Dogs tend to have one or two systemic signs, generally polyarthritis with skin or renal manifestations, with less frequent occurrence of hematological and central nervous system impairment (Fournel et al., 1992; Day, 2008).

Most authors agree that the canine patient should be considered as having SLE when you get one or two of the following disorders: peripheral blood cytopenia, oligoarthritis or polyarthritis, glomerulonephritis, focal or multifocal signs of central nervous system impairment, dermatitis, polymyositis, myasthenia gravis, or vasculitis associated with a positive ANA test or lupus erythematosus cells (LE cells) positive (Kass et al., 1985; Bennett, 1987; Jones, 1993; Tizard, 2004). Since polyarthritis is the most common clinical sign of SLE in dogs, other causes of polyarthritis should be considered.

This paper aims to describe a case of polyarthritis in a dog with SLE without evidences of skin or kidney involvement, the results of laboratory tests and the use of microalbuminuria to rule out renal injury, as well as the treatment outcome.

\section{CASE REPORT}

A five year old male mongrel dog, with $8 \mathrm{~kg}$ of body weight was received for medical consultation. During the anamnesis, the owner reported that the animal showed limited mobility and movement of the limbs and neck, weight loss, apathy, hyporexia and intermittent symmetrical increase volume in both joints of the forelimbs and hindlimbs, mostly alternating between the tibial-tarsal and carpus joints. The signs started approximately 4 months before.

At the time of consultation, the animal was in treatment for the last 30 days with carprofen 4.4mg.kg-1 SID PO, associated with amoxicillin and clavulanate potassium $20 \mathrm{mg}+4 \mathrm{mg}$.kg-1 BID $\mathrm{PO}$, with no significant improvement. X-rays of the carpal and tarsal joints were normal.

On physical examination, moderate generalized lymphadenopathy and ulcerative lesions in the oral mucosa on the lateral edge of the tongue were observed (Figure 1a). Under general anesthesia, synovial fluid of knee, carpal and humerus-skapular joints were collected. Blood and urine samples were also collected for biochemical tests (alanine aminotransferase, urea and creatinine), complete blood count, ANA, urinalysis, and determination of microalbuminuria.

Treatment after the laboratory tests results was prednisone 3mg.kg-1 SID PO for 14 days, 2mg.kg-1 SID PO, for 28 day, 1mg.kg-1 PO for 28 days and, finally, 0.5mg.kg-1 SID PO for 30 days, always maintaining contact with the owner for evaluation of therapeutic response and possible dose reduction.

\section{DISCUSSION}

This dog was presented with movement difficulty due to LES arthralgia. No evidence of trabecular bone density loss was found on limb $\mathrm{X}$-rays, which could tilt the diagnostic hypotheses towards erosive polyarthritis. 
Hematological finds were neutropenia (3.680. $\mu \mathrm{L}-1)$ and lymphopenia (460. $\mu \mathrm{L}-1)$. Leukopenia in SLE involves significant loss of CD8 + T cells, with a somewhat smaller loss of CD4 + T cells (Tizard, 2004). Platelet count was slightly below the reference limits $(180.000 . \mu \mathrm{L}-$ 1 ). There was no evidence of hemolytic anemia.

Biochemical profile and urinalysis were normal. Only traces of albumin (less than $0.25 \mathrm{mg} . \mathrm{dL}-1$ ) were present in microalbuminuria measurement. Microalbuminuria has been used as a predictor of excess cardiovascular morbidity and mortality in hypertensive, diabetic and renal human subjects (Kilaru and Bakris, 1994), and is associated with various underlying diseases in dogs (Whittemore et al., 2006). These results can rule out any significant kidney damage due to SLE. The presence of ulcerative lesions in the oral mucosa and tongue are common in SLE, and may result from vasculitis by immune complex deposition in arteriolar walls, resulting in fibrinoid necrosis and local fibrosis (Tizard, 2004). Pyrexia, lymphadenopathy and splenomegaly (Bennett, 1987; Fournel et al., 1992) may also be present, however, only lymphadenopathy was present in this case.

Synovial fluid cell count was 15.000 leucocytes. $\mu \mathrm{L}-1$, with neutrophils predominance (73\%), characterizing an inflammatory arthropathy. LE cells were observed in the synovial fluid, which can be formed by amorphous nuclear material opsonized by AAN and phagocytosed by neutrophils (Fig. 1b) (Tizard, 2004). The result of ANA test in cell line Hep-2 was positive with titration of 1/1,280 in homogeneous nuclear pattern, highly predictive of SLE. The autoantibodies were reactive to the nucleus and chromosomal metaphase plate, but were not to the nucleolus, cytoplasm and mitotic apparatus.

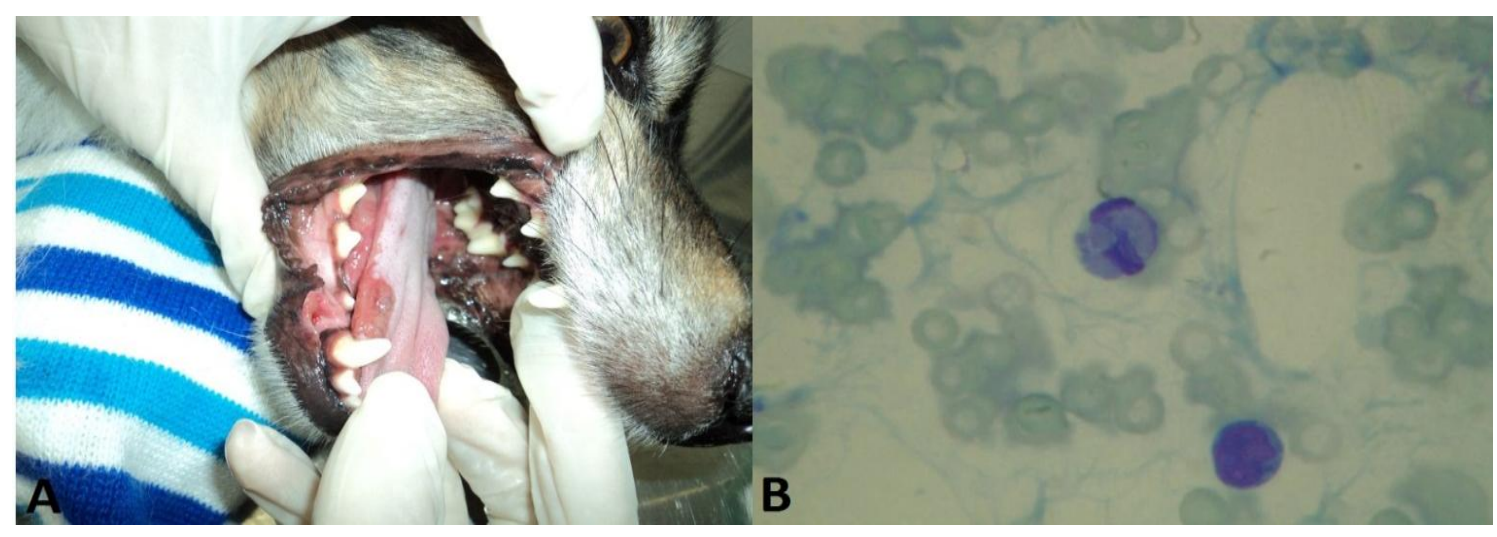

Figure 1. Ulceration at the tongue border (A); neutrophil with phagocytized material, featuring a LE cell (B).

Five criteria were found in this case, allowing the diagnosis of SLE: oral ulcers, nonerosive arthritis, hematologic abnormalities (neutropenia and lymphopenia), presence of LE cells in synovial fluid and positive ANA.

In most severe cases, treatment with $2.2 \mathrm{mg} . \mathrm{kg}-1$ SID of prednisone or prednisolone is indicated, with dose reduction after disease remission, and sub sequentially at every four weeks (Stone, 2004). If clinical signs return before lower maintenance levels of glucocorticoids are achieved, the animals should be treated with a combination therapy. The recommended minimal duration of therapy is six months (Stone, 2004).

Cyclophosphamide and azathioprine are the drugs of choice for combination therapy (Stone, 2004). Sustained remission of up to nine years in $55.6 \%$ of dogs with SLE using combination therapy with levamisole can be achieved (Fournel et al., 1992); glucocorticoids was used only initially. This patient had complete remission of clinical signs with a minimum $0.5 \mathrm{mg} . \mathrm{kg}-1 \mathrm{SID}$ prednisone dose. 


\section{CONCLUSIONS}

The occurrence of systemic lupus erythematosus without other classical signs, such as dermatological or renal involvement, demonstrates the importance of performing additional tests and procedures, such as analysis of synovial fluid and FAN in every case where polyarthritis is the main clinical sign. In addition, microalbuminuria measurement can be an important test to determine the presence of kidney damage in an early stage, which has a worse prognosis.

\section{REFERENCES}

BENNETT, D. Immune-Based Nonerosive Inflammatory Joint Disease of the Dog. 1. Canine Systemic Lupus-Erythematosus. J. Small Anim. Pract., v.28, p.871-889, 1987.

COSTA, O.; FOURNEL, C.; LOTCHOUANG, E. et al. Specificities of Antinuclear Antibodies Detected in Dogs with Systemic Lupus Erythematosus. Vet. Immunol. Immunopathol., v.7, p.369-382, 1984.

DAY, M.J. Multisystem and Intercurrent Immune-Mediated Disease. In: DAY, M.J. Clinical Imunnology of the Dog and Cat. 2.ed. London: Manson, 2008. Cap.14, p.356-368.

FOURNEL, C.; CHABANNE, L.; CAUX, C. et al. Canine Systemic Lupus Erythematosus. I: A Study of 75 Cases. Lupus, v.1, p.133-139, 1992.

HOCHBERG, M.C. Updating the American College of Rheumatology Revised Criteria for the Classification of Systemic Lupus Erythematosus. Arthritis Rheum, v.40, p.1725, 1997.
JONES, D.R. Canine Systemic Lupus Erythematosus: New Insights and Their Implications. J. Comp. Pathol., v.108, p.215-228, 1993.

KASS, P.H.; FARVER, T.B.; STROMBECK, D.R. et al. Application of the Log-Linear and Logistic Regression Models in the Prediction of Systemic Lupus Erythematosus in the Dog. Am. J. Vet. Res., v.46, p.2340-2345, 1985.

KILARU, P.; BAKRIS, G.L. Microalbuminuria and Progressive Renal Disease. J. Hum. Hypertens., v.8, p.809-817, 1994.

MONESTIER, M.; NOVICK, K.E.; KARAM, E.T. et al. Autoantibodies to Histone, DNA and Nucleosome Antigens in Canine Systemic Lupus Erythematosus. Clin. Exp. Immunol., v.99, p.3741, 1995.

MONIER, J.C.; FOURNEL, C.; LAPRAS, M. et al. Systemic Lupus Erythematosus in a Colony of Dogs. Am. J. Vet. Res., v.49, p.46-51, 1988.

STONE, M. Systemic Lupus Erythematosus. In: ETTINGER, S.J.; FELDMAN, E.C. Textbook of Veterinary Internal Medicine. 6.ed. Philadelphia: Saunders, 2004. Cap.277, p.1952-1957.

TIZARD, I.R. The Systemic Immunological Diseases. In: TIZARD, I.R. Veterinary Immunology: An Introduction. 7.ed. Philadelphia: Saunders, 2004. Cap.34, p.400411.

WHITTEMORE, J.C.; GILL, V.L.; JENSEN, W.A. et al. Evaluation of the Association between Microalbuminuria and the Urine Albumin-Creatinine Ratio and Systemic Disease in Dogs. J. Am. Vet. Med. Assoc., v.229, p.958963, 2006. 